\title{
Nafaka Yükümlüsünün Nafakası ile Sorumlu Olduğu Kimselere Zekât Vermesinin Fıkhi Açıdan Değerlendirilmesi
}

\section{Evaluation Of The Intelligence Of Nafaka Obligation To The Persons That Are Responsible For The Participation}

\author{
Muhammed ÇUÇAK \\ Dr. Öğr. Üyesi., Osmaniye Korkut Ata Üniversitesi, İlahiyat Fakültesi, İslam \\ Hukuku Anabilim Dalı. \\ Dr. Lecturer. Member, Osmaniye Korkut Ata University, Faculty of Theology, \\ Department of Islamic Law. \\ Osmaniye, Turkey \\ muhammedcucak@osmaniye.edu.tr
}

ORCID: 0000-0003-3177-4837

Geliş Tarihi: 21.01.2019, Kabul Tarihi: 17.05.2019

DOI: $10.34085 /$ buifd.515502

Öz

Malî ibadetlerin başında gelen zekât, İslâm'ın beş temel esaslarından biridir. Zekât ile ilgili meseleler, geçmişte olduğu gibi günümüzde de âlimler ve araştırmacıların ilgi odağı olmaya devam etmektedir. Zekât, klasik kaynaklarda kitabın içindeki bir başlık altında ele alınırken, günümüzde kimi zaman müstakil kitapların, kimi zaman makalelerin konusu olmaktadır. Zekât, içinde birden fazla mesele ve konu barındırmaktadır. Bunların içinde üzerinde fakihlerin ittifak ettiği meseleler olduğu gibi ihtilaf ettiği meseleler de vardır. Üzerinde ihtilafın yaşandığı meselelerden biri de zekâtın kimlere verilip verilmeyeceğidir.

Fakihler, zekâtın nelere verileceği konusunda birkaç sınıf üzerinde ittifak etmiştir. Ancak söz konusu sınıfların kapsamı içine kimlerin dâhil edilip edilmeyeceği hakkın- 
da ihtilafa düşmüşlerdir. Örneğin, anne baba gibi yakın akrabalara zekât verilmesi ihtilaf edilen konulardandır. Fakihlerin ekseriyetine göre anne baba gibi kendisine nafakası vacip olan kimselere zekât verilmesi caiz görülmezken, bir kısım fakihe göre kimi durumlarda onlara zekât verilmesinde bir sakınca bulunmamaktadır. İşte bu çalışmamızda anne-baba, çocuklar ve eş gibi nafaka hakkı olan kimselere zekât verilip verilmeyeceği konusu ele alınacaktır.

Anahtar Kelimeler: Zekât, Zekâtın verileceği yerler, Nafaka, Anne-Baba, Çocuklar.

\section{Abstract}

The zakat in the beginning of financial worship, is one of the five basic principles of Islam. Issues related to intelligence continue to be the center of attention of scholars and researchers as in the past. While Zakat is discussed under classical titles in the book, it is sometimes the subject of independent books and sometimes articles in our age. Zakat contains more than one issue and subject. In these, there are some issues in which there are disputes, as are the issues of the alliances. One of the issues on which the dispute is experienced is the question of who will not be given and who will be given.

The Fakihs allied themselves with several classes on the place where the zakat was to be given. However, they disagreed about who may be involved in the scope of the class. The issue of giving zakat to close relatives like parents is controversial. According to the majority of Fakih, while it is permissible to give zakat to those who like him or her as a parent. in some cases there is no harm in giving them zakat according to some of them. In this study, whether parents, children and spouses like alimony will be given will be discussed.

Keywords: Zakat, places where intelligence is given, Alimony, Parents, Children.

\section{GíRiș}

Zekât ibâdeti İslam hukukunda "ز ز z-ka" kelimesinden türeyen "زكاة z-k-a-t” kelimesi ile ifade edilmiştir. Mezkûr kelime Arapça olup sözlükte; "büyümek, artmak, arındırmak, bereket, övmek, iyi olmak” manalarına gelmektedir. ${ }^{1}$ Zekât, Kur'an-1 Kerim'de "zekât” sözcüğünün yanı sıra "sadaka” örneğin: (et-Tevbe 9/60), bazen "hak” örneğin: (ez-Zâriyât 51/19), kelimeleriyle de ifade edilmiş olup oldukça sık

1 Ebû'l-Fazl Cemaluldin Muhammed b. Mükerrem b. Menzûr el-İfrikî el-Misrî, “z-k-v”, Lisânül-Arab, (Beyrut: Dârü Sadır, ts.), 14: 358; es-Seyyid Murteza el-Hüseyn ez-Zebidi, "z-k-v", Tâcu'l-Ârûs min cevâhiri'-Kāmûs, thk. Abdu's-Subûr Şâhîn, (Kuveyt: el-Meclisu'lVatanî li's-Sikâfe ve'l-Funûn ve'l-Edeb, 1422/2001), 38: 220; Butrus el-Bustânî, "z-k-v", Muhîtu'l-muhît, (Beyrut: Mektebetü Lübnan, 1407/1987), 375; Mecme'ü'l-luğâti'l-Arabiyye, “z-k-v", el-Mu'cemü'l-vesît, 2. bs. (İstanbul: el-Mektebetü'l-Islamiye, ts.), 396. 
zikredilmiştir. Şöyle ki Kur'an'da yirmi yedi yerde "namaz" tabiri ile birlikte ve üç yerde de tek başına zikredilmek üzere toplam otuz yerde geçmektedir. ${ }^{2}$ Fıkıh literatüründe zekâtın tanımı, her mezhep tarafından farklı tabirler ile yapılmış olsa da genel olarak: "Belli bir tür malın belli bir miktarını, belirli bir kimseye zorunlu olarak vermekten ibarettir." şeklinde yer almıştır. ${ }^{3}$ Zekâtın, dünyada malın bereketini; ahirette ise sevabını arttırdığından ve zekât veren kimseyi günahlardan arındırdığından mezkûr kelimeyle ifade edildiği ileri sürülmüştür. ${ }^{4}$ Zekât, kelime şehadet ve namaz gibi İslam'ın farziyeti kat'i olan beş şarttan ve önemli rükünlerinden biridir. Farziyeti ise Kur'ân, sünnet ve icmâ ile sabittir. ${ }^{5}$

İslâmî literatürde zekâtın farz kılındığı zaman ve yeri ile ilgili genel eğilim, zekâtın hicretin ikinci yılında Medine' de farz olduğu yönündedir. ${ }^{6}$ Ancak kaynaklar dikkatli taranıp incelendiğinde zekâtın Mekke ve Medine dönemi olmak üzere birkaç aşamada tedrici bir şekilde farz kılınmış olduğu anlaşılmaktadır. Zekât, Mekke'de miktarı ve nisabı belirtilmeden mücmel bir şekilde farz kılınmıştır. Zira onunla ilgili inen ayetlerin içinde Mekke'de inmiş ayetler de vardır. ${ }^{7}$ Medine'de hicretin ikinci yılda zekâtın miktarı ve nisapları açıklanmıştır. ${ }^{8} \mathrm{Bu}$, âlimlerin zekâtın hicrî ikinci yılında Medine'de farz kılınmış olduğu kanaatine varmasının nedenidir. Hicretin dokuzuncu yılına gelindiğinde ise zekâtın kimlere ve hangi sınıf kişilere verileceği

2 Said b. Ali b. Vahpe el-Kahtânî, ez-Zekât fit-İslam, 3. bs. (Kasb: Merkezü'd-De've ve'l-İrşâd, 1431/2010), 15.

3 Ali b. Muhammed es-Seyyid eş-Şerif el-Cürcânî, "ez-Zekât", Mu' cemü't-ta'rîfât, thk. Muhammed Sıddık el-Minşâvî, (Kahira: Dârü'l-Fadile, ts.), 99.

4 Şemsüleimme Ebû Bekr Muhammed b. Ebi Sehl es-Serahsî, el-Mebsût, (Beyrut: Dârü'1Me'rife, 1409/1989), 2: 149.

5 Alâeddin Ebû Bekr b. Mes'ud el-Kāsânî el-Hanefî, Bedaiü's-sanâi' fî tertibi'ş-şerâi', thk. Ali Muhammed Muavvez ve Adil Ahmet AbdülMevcud 2. bs. (Beyrut: Dârü'l-Kütübi'lİlmiyye, 1424/2003), 2: 371; Ebû Muhammed Muvaffakuddin Abdullah b. Ahmet İbn Kudâme, el-Mugnî, thk. Abdullah b. Abdülmuhsin Türkî ve Abdülfettah Muhammed elHulv, 3. bs. (Riyad: Dârü Âlemi'l-Kütüb, 1417/1997), 4: 5.

6 Şihâbüddin Seyyid Mahmud Âlûsî el-Bağdadî, Rûhu'l-meânî fî̀ tefsîri'T-Kur'âni'-azîm, (Beyrut: Dârü İhyai't-Türâsi'1-Arabî, ts.), 13: 221; Muhammed Reşid Rizâ, Tefsirül'-menâr, 2. bs. (Kahira: Dârü'l-Menâr, 1366/1947), 4: 275; Vehbe ez-Zuhaylî, el-Fıkhu'-İslâmî ve edilletuh, 3. bs. (Beyrut: Dârü'l-Fikr, 1409/1989), 2: 733; Hayreddin Karaman, İslâm hukuku tarihi, (İstanbul: Nesil Yayınları, 1409/1989), 84.

7 Meselâ bk. el-A'raf 7/156; el-Enbiya 21/73; Fussilet 41/7.

8 Ebû'l-Fida İmadüddin İsmail b. Ömer İbn Kesir, Tefsirül-Kur'anil-azîm, thk. Sami b. Muhammed es-Selâme, 2. bs. (Riyad: Dârü Tayyib li'n-Neşr ve't-Tevz, 1420/1999), 5: 259; Heyet, "İslam", el-Mevsû̂âtu'-fikhiyye, 2. bs. (Kuveyt: Vizâretü'l-Evkâf ve'ş-Şuûni'lİslâmiyye, 1406/1986), 4: 270; Muhammed b. Salih el-Useymîn, Fetâva fi ez-zekât ve's-siyâm, nşr. Fahd b. Nasir b. İbrahim es-Süleyman, (Riyad: Dârü's-Süreyya, 1429/2008), 15. 


\section{Muhammed ÇUÇAK}

tafsili bir şekilde beyan edilerek zekâtla ilgili hükümler tamamlanmıştır. Böyle bir sonuca varmamızı sağlayan amil, zekâtın ne gibi yerlere verileceğini açıklayan ayetin yer aldığı tövbe suresinin hicri dokuzuncu yılda inmiş olmasıdır. ${ }^{9}$

Çalışmamızda önce zekâtın verileceği sınıflar tespit edilmeye çalışılacak, sonra çalışmamızın asıl konusu olan anne-baba ve eş gibi nafakası vacip olan kimselere zekât verilip verilmemesi konusunda fakihlerin görüşlerine ve kendi değerlendirmelerimize yer verilecektir.

\section{ZEKÂTIN VERILECEĞİ SINIFLAR}

Açıklaması Kur'an'da yer alan zekâtla ilgili hükümlerin biri de zekâtın verileceği yerlerdir. Kur'an'da zekâtın miktarına ve nisaplarına yer verilmezken zekâtın kimlere verileceği detaylı bir şekilde ortaya konulmuştur. Konuyla ilgili ayet şudur: “Sadakalar (zekâtlar), Allah’tan bir farz olarak ancak fakirler, düşkünler, zekât toplayan memurlar, kalpleri İslâm'a 1sındırılacak olanlarla (özgürlüğüne kavuşturulacak) köleler, borçlular, Allah yolunda cihad edenler ve yolda kalmış yolcular içindir. Allah, hakkıyla bilendir, hüküm ve hikmet sahibidir." (et-Tevbe 9/60).

Ayetten zekâtın sekiz sınıfa verileceği anlaşılmaktadır. Fakihler arasında söz konusu sınıfların tamamına zekât verilip verilmeyeceği hususunda kayda değer bir ihtilaf yoktur. Ancak mezkûr sınıfların kapsamına kimlerin gireceği hususu ihtilaflıdır. Adı ayette geçen sekiz sınıfla ilgili fakihlerin görüşleri şöyledir:

\subsection{Fakirler}

Zekâttan pay verileceklerin en başında fakir sınıfı zikredilmiştir. Fakir kelimesi sözlükte; omurgası kırık, suyun kaynağı ve muhtaç manalarına gelmektedir. ${ }^{10}$ Ancak zekâtın sarf yerlerinden biri olarak "fakir" kelimesinden kimlerin kastedildiği konusunda fakihler ihtilafa düşmüşlerdir.

Hanefîler ve Mâlikîler'e göre fakir, kendi ihtiyaçlarını ancak karşılayabilecek nisap miktarı veya daha az malı bulunan ya da mal-mülkü nisap miktarına ulaşan ancak senelik ihtiyaçlarını karşılamaya yetmeyen kimsedir. ${ }^{11}$

9 Ebû Bekr Ahmet b. Ali er-Râzî el-Cessâs, Ahkâmü'l-Kur'ân, thk. Muhammed es-Sadık Kamhavi, (Beyrut: Dârü İhyai't-Türâsi'l-Arabî, 1412/1992), 4: 255; Vehbe ez-Zuhaylî, etTefsirü l-münir: fi l-akideti ve `ş-şeria`ti ve l-menhec, 10. bs. (Dımaşk: Dârü'l-Fikr, 1430/2009), 5: 439 .

10 İbn Menzûr, "f-k-r", 5: 60; ez-Zebidi, "f-k-r", Tâcu'l-Ârûs min cevâhiri'l-Kāmûs, thk. Hüseyin Nessâr, (Kuveyt: Vizâretü'l-Ii'lâm, 1394/1974), 13: 334.

11 Kāsânî, Bedaiü's-sanâi', 2: 466; Kemâleddin Muhammed b. Abdülvahid b. Abdülhamid İbnü'l-Hümâm, Şerhü Fethi'l-Kadîr, thk ve thrc. Abdurrezzak Gālip el-Mehdi, (Beyrut: 
Şâfiîler ile Hanbelîlerce fakir, hasta olsun olmasın, dilensin dilenmesin, meslek sahibi olsun olmasın kendi ihtiyaçlarını karşılamaya gücü yetmeyen veya hiç geliri olmayan ya da geliri ancak kendi ihtiyaçlarının yarısını bile karşılamaya yetmeyen kimsedir. $^{12}$

\subsection{Miskinler}

Kur'an'ın sıralamasına göre zekâttan pay verilecek sınıfların ikincisi miskinlerdir. Miskin, "s-k-n" den türemiş olup bu kelime sözlükte; sakinleşmek, hareketsiz olmak, yerleşmek, acının dinmesi ve susmak gibi anlamlara gelmektedir. Miskin ise yoksul, fakirlikten hareketi kısıtlanan, sefil ve zavallı kimselere denmektedir. ${ }^{13}$ Zekâttan pay alacak sınıflardan biri olarak "miskin" ibaresinden kimlerin kastedildiği konusunda fakihler farklı görüşlere sahiptirler:

Hanefîler, miskini hiç geliri olmayan ve kendi ihtiyaçlarını karşılamak için dilenmeye muhtaç kimse olarak tanımlarken Mâlikîler ise miskinin elinde hiçbir şey bulunmayan kimse olduğunu söylemişlerdir. ${ }^{14}$

Dârü'l-Kütübi'l-İlmiyye, 1424/2003), 2: 265-266; Şeyh Nizam el-Burnehâbûrî ve Heyet, el-Fetâva'1-Hindiyye, zbt ve tsh. Abdullatif Hasan Abdurrahman, (Beyrut: DârülKütübi'l-İlmiyye, 1421/2000), 1: 206; Muhammed Emin b. Ömer b. Abdülaziz ed- Dımaşki İbn Âbidîn, Hâşiyetu İbn Âbidîn, reddül-muhtâr alâ dürri'-muhtâr, thk. Adil Ahmet Abdülmevcud, Ali Muhammed Muavviz, (Riyad: Dârü Âlemi'l-Kütüb, 1424/2003), 3: 283-284; Şemsüddin eş-Şeyh Muhammed Urfe ed-Dusûkî, Hâşiyetü'd-Dusûkî ale'ş-Şerhi'tkebîr, (Kahire: Dârü Ihyâ'i 'l-Kütübi 'l-'Arabiyya, ts.), 1: 492; Ahmet b. Muhammed es-Sâvî el-Mâlikî, Bulgatü's-sâlik li-Akrebil-mesâlik ala Şerhi's-Sagâr, tsh. Muhammed Abdüsselam Şahin, (Beyrut: Dârü'l-Kütübi'l-İlmiyye, 1415/1995), 1:425; Muhammed el-Arabî el-Karevî, el-Hulâsatu'-fikhiyye alâ mezhebi's-sâdeti'l-Mâlikiyye, (Beyrut: Dârü'l-Kütübi'l-İlmiyye, ts.), 1: 176 .

12 Muhammed b. İdris Şâfiî, el-Ümm, thk. Rıfat Fevzi Abdülmuttalib, (Mensura: Dârü'l-Vefa, 1422/2001), 3: 182; Ebü'l-Hasan Ali b. Muhammed b. Habib el-Mâverdî, el-Hâvi'l-kebîr fi fikhı mezhebi'ş-Şafî,, thk. Ali Muhammed Muavviz ve Adil Ahmet abdülmevcud, (Beyrut: Dârü'l-Kütübi'l-İlmiyye, 1414/1994), 8: 487; Ebû Zekeriyyâ Muhyiddin Yahyâ b. Şeref b. Nuri en-Nevevî, el-Mecmî̀' Şerhü̈l-mühezzeb li'ş-Şîrâzî, thk. Muhammed Necib Mutî, (Cidde: Mektebetü'1-İrşad, ts.), 6: 171; Alâeddin Ebû'1-Hasan Ali b. Süleyman el-Merdâvî, el-İnsâf fì ma'rifeti'r-râcih mine'l-hilaf alâ mezhebil-imamil-mübeccel Ahmet b. Hanbel, tsh ve thk. Muhammed Hamid F1ki, 2. bs. (Beyrut: Dârü İhyai't-Türasi'l-Arabî, 1374/1986), 3: 218; Şeyh Mansur b. Yunus b. İdris el-Hanbelî el-Buhûtî, Keşşâfül-knnâ' ani'-iknâ', thk. Lecnetün Mütehassisetün fi Vizâreti'1-Adli, (b.y. 1421/2000), 5: 117.

13 İbn Menzûr, "s-k-n", 13: 211 ve 214; Bustânî, "s-k-n", 418; el-Mu'cemül-vesît, "s-k-n”, 440.

14 Kāsânî, Bedaiü's-sanâi', 2: 466; İbnü'-Hümâm, Şerhü Fethi'-Kadîr, 2: 266; el-Fetâva'lHindiyye, 1: 206; Hâşiyetu İbn Âbidîn, 3: 284; Hâşiyetü'd-Dusûkî, 4: 432; Sâvî, Bulgatü's-sâlik, 1: 425; Karevî, el-Hulâsatu'l-fikhiyye, 1: 179. 
Şâfiîler ve Hanbelîler'e göre miskin; dilensin dilenmesin, bir meslek sahibi olsun olmasın, ihtiyaçlarının çoğunu karşılayabilecek gelire sahip kimsedir. ${ }^{15}$

\subsection{Zekât Toplama Memurları}

Ayette belirtildiği gibi zekâttan pay verilecek sınıfların üçüncüsü zekât toplayan memurlardır. Bu ayet, zekât toplama ve dağıtma işlerini devletin veya bir kurumun yürütebileceğine işaret etmektedir. Zekâtı toplayanlar, kayda geçirenler, muhafaza edenler, ihtiyaç sahiplerinin tespitini yapanlar ve dağıtanlar zekât memuru sınıfına dâhildirler ve zekâttan pay alabilirler. Fakihler, zekât memurlarının adâlet sahibi, hür, bulûğa ermiş, zekâtla ilgili hükümleri bilmiş, akıllı, güvenilir kişiler olmaları gerektiği şartını ileri sürmüşlerdir. ${ }^{16}$

Fakihler zekât memurlarında bulunması gereken şartları kendi döneminin şartlarına göre ortaya koymuş olsalar bile bu şartların ekseriyetinin yaşadığımız çağın kriterlerini taşıdığını ve onların günümüzde de zekât memurlarında bulunması gereken şartlar olduğunu düşünmekteyiz. Bu şartlara ek olarak günümüzde zekât memurlarının özellikle yurt dışına gidecek olanların gideceği yerin dilini ve örfâdetlerini bilmesi, halkı İslam ile yeni tanışan yerlere gidecek olanların onlara İslam’1 anlatabilecek kadar bilgili olması gerektiğini söyleyebiliriz.

\subsection{Kalpleri İslâm'a Isındırılacak Olanlar (Müellefe-i Kulûb)}

Bu, İslam'ın ilk çağlarında Ebû Süfyan (ö. 30/650), Sefvân b. Ümeyye (ö. 35/655) gibi kāfirlerden ve Adî b. Hatem (ö. 68/688), Uyeyne b. Hisn (ö. 30/650) gibi İslam ile yeni tanışan kişilerden oluşan sınıftır. Bu sınıfta yer alanlar genelde kendi kavmi ve aşiretinde söz ve güç sahibi kişilerdi.

Ayetin gereği Peygamber (a.s.v.)'in döneminde bunlara zekâttan pay veriliyordu. Sebebi ise onları İslam'a 1sındırmak veya onlardan gelebilecek herhangi bir tehlikeyi önlemek ya da onları İslam üzerinde tutmaktı. Hz. Ebû Bekir (ö. 13/634) dönemine gelindiğinde Hz. Ömer'in (ö. 23/644) önerisiyle söz konusu kişilerin zekâttaki payı iptal edilmiştir. ${ }^{17} \mathrm{~Hz}$. Ömer' in bu davranışıyla Peygamber (a.s.v.)' in vefatından sonra

15 Şâfiî, el-Ümm, 3: 182; Mâverdî, el-Hâvi'l-kebîr, 8: 487; Nevevî, el-Mecmû', 6: 171; Merdâvî, el-inssâf, 3: 218; Buhûtî, Keş̧âfül-kınâ', 5: 117.

16 Serahsî, el-Mebsût, 3: 9; Kāsânî, Bedaiü's-sanâi', 2: 467; Hâşiyetu İbn Âbidîn, 3: 284; Şehabeddin Ahmet b. İdris el-Karâfî, ez-Zahîre, thk. Muhammed Hacci, (Beyrut: Dârü'1Garbi'1-İslâmî, 1414/1994), 3: 145-146; Ebû'-Kasım Muhammed b. Ahmet b. Cüzey elKelbi el-Mâlikî el-Gırnâtî, el-Kevâninül-fikhiyye, thk. Muhammed b. Seydi Muhammed Mevlay, (b.y. ts.), 214; Şâfiî, el-Ümm, 3: 183; Mâverdî, el-Hâvi'l-kebîr, 8: 493-495; Merdâvî, el-İnsâf, 3: 223; Buhûtî, Keşsâfü̈l-kınâ', 5: 126-127.

17 Muhammed b. Yusuf, Ebû Hayyan el-Endülüsî, el-Bahrul-muhît, thk. Adil Ahmet AbdülMevcud ve Ali Muhammed Muavvez, (Beyrut: Dârü'l-Kütübi'l-İlmiyye, 1413/1993), 5: 59; Âlûsî, Rûhu' l-meânî, 10: 122; Reşid Rızâ, Tefsirül-menâr, 10: 574; Serahsî, el-Mebsût, 3: 
bu gibi kişilerin zekâttaki payının kalkmış olduğu Hanefîler ve çoğu Mâlikîler'in görüşüdür. Bazı Hanefîler'e göre bu hususta sahabenin icmâsı vardır. Ancak kimi fakihe göre bu sınıf kişilerin zekâttaki payı kıyamete kadar devam edecektir. ${ }^{18}$

\subsection{Köleler}

Zekât sınıfları içinde zikredilen kölelerden kimlerin kastedildiği erken dönemden itibaren ihtilaf konusu olmuştur. Kimileri, bunların hürriyetine kavuşmak için efendisiyle anlaşma yapan köleler olduğunu savunurken kimileri de bunların sadece efendisiyle anlaşma yapan değil, mutlak köleler olduğunu savunmuşlardır.

Bunların efendisiyle anlaşma yapan kölelerin olduğunu savunanlar; Ali b. Ebî Talib (ö. 40/661), Said b. Cübeyr (ö. 95/713), İbni Şihab ez-Zührî (ö. 124/741), İbrahim en-Nehaî (ö. 96/714), Ebû Hanife (ö. 150/767), Leys b. Sa'd (ö. 175/791), es-Sevrî (ö. 161/777) ve Şâfiîler' dir. Ahmed b. Hanbel'in (ö. 241/855) bir görüşü bu doğrultudadır. Zekâttan pay alacak kölelerin mutlak köleler olduğunu savunlar ise Abdullah b. Abbas (ö. 68/687), Hasan el-Basrî (ö. 110/728), imam Mâlik (ö. 179/795), Ubeydullah b. Hasan el-Anberî (ö. 168/784) ve Ebû Sevr (ö. 246/860)' dir. Bir rivayete göre Ahmed b. Hanbel de bu görüştedir. Bu görüş sahiplerine göre azat edilen kölenin velayetinin, azat edene değil tüm müslümanlara veya devlete ait olması şartıyla zekât için ayrılan para ile köle satın alıp onu azat etmek caizdir. Kimi Hanbelî́ye göre köle sınıfı için ayrılan payın müslüman esirleri kurtarmak için kullanılması da caizdir. ${ }^{19}$

\subsection{Borçlular}

Hanefîlerce bunlardan maksat borçlu olup elindeki mal nisap miktarına ulaşmayan veya başkalarına borç verip onu alamayan ve elinde ise nisap miktarından daha az mal olan kimselerdir. Çünkü Hanefîler, ayetteki "el-Ğarimîne" kelimesinin hem borçluyu hem de borç sahibini ifade ettiğini ileri sürmüşlerdir. Hanefîler'e göre borçlulara zekât vermek fakirlere zekât vermekten daha iyidir. Hanefî kaynaklarda borçlunun borcu hangi amaç için aldığı ile ilgili herhangi bir kayıt bulunmamaktadır. ${ }^{20}$

9; Hâşiyetu İbn Âbidîn, 3: 287-288; Karâfî, ez-Zahîre, 3: 146; Mâverdî, el-Hâvi'-kebîr, 8: 499500.

18 Ebû Hayyan, el-Bahru'l-muhît, 5: 59; Kāsânî, Bedaiü's-sanâi', 2: 470-471; Buhûtî, Keş̧̧ấülkınâ', 5: 136-137.

19 Serahsî, el-Mebsût, 3: 9-10; Hâşiyetu İbn Âbidîn, 3: 286-287; Karâfî, ez-Zahîre, 3: 146-147; Sâvî, Bulgatü's-sâlik, 1: 428; Mâverdî, el-Hâvi'7-kebîr, 8: 502-504; Nevevî, el-Mecmû', 6: 183190; Merdâvî, el-İnsâf, 3: 228-232; Buhûtî, Keşşâfül-knnâ', 5: 140-144. 
Mâlikîler, bunların içki içmek ve kumar oynamak gibi kötü işler için değil ailesini geçindirmek için borç alan kimseler olduğunu ileri sürmüşlerdir. Aldığı borcu kötü işlere kullanan sonra tövbe eden kimseye zekât verilmesi ihtilaflıdır. Mâlikîler borçluya zekâttan pay verilmesi için borçlunun borcu ödeyecek durumda olmamasını, borcun zekât ve keffaret gibi Allah borcu değil insanlara ait borç olmasını, zekât verildiğinde borçlunun durumunda bir iyileşmenin bulunmasını ve borcu zaruri ihtiyaçları için almış olmasını şart koşmuşlardır. ${ }^{21}$

Şâfiîler ve Hanbelîler'e göre borçlulardan maksat kendi menfaati veya toplumun maslahatı için borç alıp onu ödemeye gücü yetmeyen kimselerdir. Bunlar, borcu ailesini geçindirmek gibi gerekli olan ihtiyaçları için kullanmak amacıyla almış olmalı ve bu konuda aşırılığa kaçmamalıdır. ${ }^{22}$

\subsection{Allah Yolunda Olanlar}

Cumhur, Allah yolunda olanlardan mücahitlerin kastedildiği görüşündedir. Müslümanların lehine ve gayrimüslimlerin aleyhine casusluk yapanlar ve sınır güvenliğini koruyanlar da zekât alabilirler. Hanefîler, mücahitlerin zekâttan pay alabilmesi için onların fakir olmasını şart koşmuşlardır. İçinde İmam Mâlik’in de bulunduğu bazı Mâlikîler, Şâfiîler ve Hanbelîler, savaş devam ettiği süre içinde zengin mücahitlerin de zekât alabileceklerini ileri sürmüşlerdir. Hanefîler ve Mâlikîler, mücahitlerin niteliği üzerinde durmazken Şâfiîler ile Hanbelîler, mücahitlerin devletten düzenli maaş alan değil gönüllü olarak savaşa katılan kişiler olmalarını şart koşmuşlardır. ${ }^{23}$

Bunlar, Allah yolunda sınıf ile ilgili ileri sürülen genel görüşler olup Fahreddin er-Râzî (ö. 604/1207) gibi bazı müfessirler ve Kāsânî (587/1191) gibi bazı fakihler, erken dönemden itibaren "Allah yolunda" sınıfının anlamının sadece mücahitleri kapsamayacağını düşünerek ona tüm hayırlı işleri dâhil etmişlerdir. ${ }^{24}$

\subsection{Yolda Kalmış Yolcular}

Bunlar, yolculuğa çıkmış ve parası bittiğinden varacağı yere varamayan kimselerdir. Hanefîler, Mâlikîler ve Hanbelîler'e göre yolda kalma sıfatıyla zekât alabilecek olanlar, sadece yaşadığı yerden ayrılan ve parası kalmadığından dolayı yolda

21 Karâfî, ez-Zahîre, 3: 147-148; Sâvî, Bulgatü's-sâlik, 1: 428-429.

22 Mâverdî, el-Hâvi'-kebîr, 8: 508-509; Nevevî, el-Mecmû', 6: 191-193; Merdâvî, el-İnsâf, 3: 233; Buhûtî, Keş̧âfül '-kınâ', 5: 144.

23 Serahsî, el-Mebsût, 3: 10; Karâfî, ez-Zahîre, 3: 148; Ebû Ömer Yusuf b. Abdullah b. Muhammed b. Abdulber en-Nemri el-Kurtubî, el-Kāfí fi fikhı ehlili-Medinetil-Mâlikî, 2. bs. (Beyrut: Dârü'1-Kütübi'l-İlmiyye, 1413/1992), 114; Nevevî, el-Mecmû', 6: 198-202; Buhûtî, Keşşâfül-kınâ', 5: 146-150.

24 Muhammed er-Râzî Fahreddin b. Allame Ziya'u'd-Din Ömer el-Müş̧ehir bi Hatîbi'r-Rey, et-Tefsîrül-kebîr, (Beyrut: Dârü'1-Fikr, 1401/1981), 16: 115; Kāsânî, Bedaiü's-sanâi', 2: 471. 
kalanlardır. Şâfiîler'e göre yolda kalan kimselerin yanı sıra henüz yaşadığı yerden ayrılmayan ve muhtemel yolda parası bitecek olanlara da zekât verilebilir. Kimi Mâlikîler'e göre bunlar hacılardır. Yolda kalanların kendi memleketlerinde zengin olmaları zekât almalarına mani değildir. Yolculuğun dini kurallara uymayan ameller veya gezip eğlenmek gibi faydasız işler için olmaması, yolcunun zekât sadece ihtiyacına yetecek kadar alması şarttır. Yolda kaldığında borç alıp memleketine dönebilecek durumda olan kimselere zekât verilip verilmemesi fakihler arasında ihtilaf konusudur. ${ }^{25}$

Yukarıda tanımı yapılan sekiz sınıfa zekât verilmesi ayet ile belirtilmiştir. Bunların zekâttan pay alabilmesi için ayette herhangi bir şart zikredilmezken fakihler ise birtakım şartları ortaya koymuşlardır. Örneğin; kalpleri İslâm'a 1sındırılacak olanlar hariç diğer sınıfların müslüman olmaları ve köleler dışında diğer sınıfların ise hür olmaları gerekmektedir. Hanefîler, zekât memurları, köleler ve yolda kalmışlar dışında diğer sınıfların fakir olmalarını şart koşarken Şâfiîler ise fakir, miskin, köleler, borcu kendi menfaati için alan borçlu ve yolda kalmış yolcuların fakir olmalarını benimsemişlerdir. ${ }^{26}$

\section{ARALARINDA NAFAKA SORUMLULUĞU BULUNAN KIMSELER}

Zengin kişinin, nafakasını karşılamakla yükümlü olduğu kimselere zekât vermenin hükmüne geçmeden önce nafakanın ne olduğu üzerinde durmak ve akrabaları içinden kimlerin nafaka almak hakkına sahip olduğunu tespit etmek gerekmektedir. Zira nafaka, alanı geniş bir kavramdır ve akrabaların tamamı nafaka yükümlüsüne yakınlık açısından aynı derecede değildir.

\subsection{Nafakanın Tanımı}

"Harcamak, tüketmek" manasına gelen "infâk" lafzından türetilen "nafaka" kelimesi sözlükte azık ve ihtiyaçların karşılanması maksadıyla harcanan para vb. maddî değerler anlamına gelir. Istılahta ise genel anlamıyla "hayatiyetin ve yararlanmanın devamlılığını sağlamak için yapılması zorunlu olan harcamalar" ${ }^{27}$ şeklinde ifade edilmiştir. Nafakanın, hayvan nafakası, iddet nafakası, hısımlık ve akrabalık nafakası gibi çeşitleri bulunmaktadır. Ancak biz burada sadece akrabalık, evlilik ilişkisinden kaynaklanan nafaka ve nafaka alması gerekli olan kimseler üzerinde

25 Serahsî, el-Mebsût, 3: 10; Karâfî, ez-Zahîre, 3: 148-149; Nevevî, el-Mecmû', 6: 202-205; Buhûtî, Keş̧̧ấül-kınâ', 5: 150-151.

26 Hâşiyetu İbn Âbidîn, 3: 283; Hâşiyetü'd-Dusûkî, 1: 492; İbn Kudâme, el-Mugnî, 8: 210.

27 Celal ERBAY, “Nafaka”, Türkiye Diyanet Vakfi İslam Ansiklopedisi (Ankara: DTV Yayınları, 1427/2006), 32: 282. 


\section{Muhammed ÇUÇAK}

duracağız. Asıl amacımız nafakayı tüm yönleriyle ortaya koymak olmadığı için konuya detaylı şekilde değil genel olarak değineceğiz.

\subsection{Nafaka Sorumlusu ve Alacaklılar}

Nafaka alacaklıları, yakınlık derecesine göre küçükten büyüğe doğru sıraya koymak gerekirse önce çocuklar, sonra anne-babalar ve bunların anne-babaları gelir. Bunlara usul ve fürû denilir. Daha sonra eşler ve kimi fakihlere göre nafaka alacak olan yakın akrabalar gelmektedir.

Çocukların nafakası babaya aittir. Küçük çocukların ve sakatlık, felç gibi kalıcı hastalık veya ilim tahsili gibi makul bir sebepten dolayı kendi ihtiyaçlarını karşılamaya gücü yetmeyen muhtaç büyük erkek çocuklarının nafakası da babanın üzerine vaciptir. Kız çocukların nafakası evleninceye kadar ve evlendikten sonra boşanması durumunda babaya aittir. Çocukların nafakayı alabilmesi için hür olmaları şarttır. Babaları ölmüş veya nafakayı veremeyecek durumdaki çocukların nafakasını, Ebû Hanife'ye göre anne ile babanın babası yani dede, Ebû Yusuf (ö. 182/798) ile Muhammed'e (ö. 189/805) göre anne, Şâfiîler ve Hanbelîlere göre dede üstlenir. Mâlikîler'e göre çocuğun nafakası ne anneye ne de dedeye aittir. ${ }^{28}$

Yaşlılık veya hastalık ya da fakirlik sebebiyle muhtaç durumdaki anne-babanın nafakası erkek olsun kız olsun imkânı olan çocuklara aittir. Bu, fakihlerin üzerinde ittifak ettiği görüştür. Hanefî, Şâfiî ve Hanbelî mezheplerine göre yoksul dede ve ninelerin nafakasını da imkânı müsait olan torunları üstlenir. Mâlikîler dede ve ninelerin nafakasından torunlarının sorumlu olmadığını ileri sürmüşlerdir. Hanbelî dışındaki diğer mezheplere göre anne-baba, dede-ninelerin farklı dinden olmaları çocuklarından veya torunlarından nafaka almalarına engel değildir. ${ }^{29}$

Hanefîlerce kardeş, amca ve teyze gibi aralarında ebedi evlenme yasağı olan yakın akrabalar, Hanbelîlerce asabe yoluyla olsun ashâbü'l-ferâiz yoluyla olsun miras yollarından biriyle mirasçı olanlar, şartların oluşması halinde karşılıklı olarak birbirinin nafakasından sorumludurlar. Mâlikîler ve Şâfiîler'e göre yakın akrabalar arasında böyle bir sorumluluk bulunmamaktadır. ${ }^{30}$

28 Kāsânî, Bedaiü's-sanâi', 5: 178; İbnü'l-Hümâm, Şerhü Fethi'l-Kadîr, 4: 371; Abdüsselam b. Seîd Tenûhî Sehnûn, el-Müdevvenetül-kübra, (Kahire: Matbaatü's-Saâde, 1323/1905), 1: 298; Sâvî, Bulgatü's-sâlik, 2: 492; Girnâtî, el-Kevâninül-fikhiyye, 362; Mâverdî, el-Hâvil-kebîr, 11: 477 ve 479; Ebû Muhammed Muvaffakuddin Abdullah b. Ahmet İbn Kudâme, el-Kāfî, thk. Abdullah b. Abdülmuhsin Türkî, (Cize: Hicr li't-Tıbâa ve'n-Neşr, 1417/1997), 5: 99 ve 103.

29 İbnü'l-Hümâm, Şerhü Fethi'l-Kadîr, 4: 375; Gırnâtî, el-Kevâninül-fikhiyye, 365; Mâverdî, elHâvi'l-kebîr, 11: 487; İbn Kudâme, el-Kāfî, 5: 99.

30 İbnü'l-Hümâm, Şerhü Fethi'l-Kadîr, 4: 378; Girnâtî, el-Kevâninül-fikhiyye, 364-365; Mâverdî, el-Hâvi'l-kebîr, 11: 491; İbn Kudâme, el-Kāfî, 5: 100. 
Kadın zengin olsun fakir olsun, müslüman olsun gayrimüslim olsun kocasına karşı kadınlık görevini yerine getirdiği süre içinde kadının nafakasının kocaya ait olacağı konusunda fakihler arasında herhangi bir ihtilaf görülmemektedir. ${ }^{31}$

Yukarıda adı geçen kişiler, şartlar meydana geldiğinde aralarında birbirine nafaka vermeleri zorunlu olan kimselerdir. Bu hususta ileri sürülen deliller "Onların (annelerin) yiyeceği, giyeceği, örfe uygun olarak babaya aittir." (el-Bakara 2/233), "Biz, insana, ana babasina iyilik etmesini emrettik." (el-Ankebût 29/8), "Fakat dünyada onlar (anne-baba) ile iyi geçin." (Lokman 31/15), ayetleri ile "Şüphesiz kişinin yediği en temiz (helal) şey, kazancından olanıdır. Kişinin çocuğu da onun kazancıdır." 32 , "Şüphesiz sizlerin yediklerinizin en temiz (helal) olanı, kazandıklarınızdan olan şeylerdir. Şüphesiz çocuklarınız da kazandıklarınızdandır." 33 ve "Sen ve malın babana aittir." 34 gibi hadislerdir.

Naslarda sadece kadının nafakasının kocaya ve anne-babanın nafakasının çocuklara ait olacağı açıkça ifade edilmiştir. Çocukların nafakasının babaya ait olmasının gerekliliği, Allah'ın “Onların (annelerin) yiyeceği, giyeceği, örfe uygun olarak babaya aittir." (el-Bakara 2/233) ayetinin "baba” kelimesinin anlamindan çıkartılmıştır. Yani yalnız baba olmak çocuğun nafakasının kendisine ait olacağına yeterli bir sebep olduğu düşünülmüştür. ${ }^{35}$ Bunların dışındaki kimselerin nafakasının ise içtihat yoluyla belirtilmiş olduğu görülmektedir. Bu durum, nafaka sorumlusu ve alacaklısının kimler olacağı ve nafaka alanının dar veya geniş tutulması hususunda fakihlerin ihtilafa düşmesine sebep olmuştur.

\section{ARALARINDA NAFAKA SORUMLULUĞU BULUNAN KIMMSELERE ZEKÂT VERILMESİ}

Kanaatimizce nafaka yükümlüsünün, nafakası ile sorumlu olan kimselere zekâtı dolaylı yoldan vermesinin caiz olmasında fakihler arasında bir ihtilaf yoktur. Meselâ; bir kimsenin zekâtının bir kurum veya devlet aracığıyla fakir veya zekât memuru olan babasına ve fakir veya zekât memuru olan oğluna verilmesinde bir sakınca yoktur.

31 İbnü'l-Hümâm, Şerhü Fethi'l-Kadîr, 4: 340; Gırnâtî, el-Kevâninül-fikhiyye, 362; Mâverdî, elHâvi'l-kebîr, 11: 409; İbn Kudâme, el-Kāfí, 5: 77.

32 Ebû Abdirrahman, Ahmet b. Şuayb en-Nesâ̂, es-Sünenül-kübrâ, thk ve thr. Hasan Abdul Mun'im Şelbî, (Beyrut: Müessesetü'r-Risâle, 1421/2001), "buyû"” 30.

33 Ebû Abdullah Muhammed b. Yezid el-Kazvinî, Sünenü İbn Mâce, thrc ve tlk. Muhammed Nasırüddin Albeni, (Riyad: Mektebetü'l-Me'ârif, t.y.), "Tirârât" 12.

İbn Mâce, "Tirârât" 12.

35 İbnü'1-Hümâm, Şerhü Fethi'l-Kadîr, 4: 372. 
Çünkü burada zekâtı asıl teslim alan taraf, kurum veya devlettir. Fakihlerin arasındaki ihtilaf ise anne-baba, dede-nine, çocuk ve torunlar gibi usul-fürûların ve kara-kocanın birbirine doğrudan zekât vermesinin caiz olup olmaması doğrultusundadır.

\subsection{Zekât Verilmesinin Caiz Olmadığını Savunanlar}

Fakihler; akrabalara zekât verilip verilmemesini nafaka meselesiyle irtibatland1rarak ele almışlardır. Bu konudaki ihtilaf ve içtihat farklılıkları delil farklılığından ziyade büyük ölçüde nafaka meselesindeki görüş ayrılıklarından kaynaklanmış olmasıyla birlikte her mezhebin konuya yaklaşımı farklı olmuştur.

Hanefîlerce aralarında zekât alıp vermenin caiz olmayacağı kimseler sadece anne-baba, çocuk, torun, dede ve ninelerdir. Yani bir kimse annesi, babası, torunu, ninesi veya dedesinden zekât alamaz veya onlara zekât veremez. Zira bu kimselerin arasında birbirinin mallarıyla faydalanma hukuku bulunmakta ve aralarında zekât verip almaları ile bir yönüyle malı kendilerine vermiş olmaktadırlar. Bu sebeple "zekât verme" eylemi tam anlamıyla gerçekleşmiş sayılmamaktadır. Bunların fakir sınıfından olmaları ile başka sınıftan olmaları arasında hiçbir fark yoktur. Hanefîler'e göre kardeş ve amcalar gibi yakın akrabalar, aralarında nafaka sorumluluğu olan kimseler olmasına rağmen birbirinin zekâtını doğrudan alabilirler. Hatta zekâtın bu gibi kimselere verilmesi daha faziletlidir. ${ }^{36}$

Mâlikîler'e göre aralarında zekât vermenin veya almanın caiz olmayacağı kimseler sadece anne-baba ve çocuklardır. Çünkü bunlar, anne hariç aralarında nafaka sorumluluğu bulunan kişilerdir. Mâlikîler dede, nine ve torunlar gibi aralarında nafaka sorumluluğu bulunmayan usul-fürûların birbirine zekât vermenin caiz olup olmaması hususunda ihtilafa düşmüşlerdir. Bu kimselere zekât vermek kimine göre caiz, kimine göre caiz değil, kimine göre mekruh ve kimine göre müstehaptır. Mâlikî metinlerinden mekruh görüşünün İmam Mâlik'e ait olduğu anlaşılmaktadır. ${ }^{37}$ Böylece Mâlikîler'in de zekât ile nafaka konusunu kimi yerlerde ayırdığı görülmektedir.

Şâfiîlerce birbirine zekât vermenin caiz olmayacağı akrabalar sadece anne-baba, çocuk, torun, dede ve ninelerdir. Bu kişilerden biri öbürüne zekât veremez ya da ondan zekât alamaz. Zira zekât ihtiyaç sahiplerine verilir, bunlar aralarında nafaka sorumluluğu bulunan kişiler olduğundan dolayı ihtiyaç sahibi olan kimse kendisine zengin akrabasından geleceği nafaka ile zengin sayılır. Bunların dışında kalan kardeş ve amca gibi yakın akrabaların kendi aralarında zekât verip almalarında bir sakınca yoktur. ${ }^{38}$

36 Serahsî, el-Mebsût, 3: 11; Kāsânî, Bedaiü's-sanâi', 2: 483; İbnü'1-Hümâm, Şerhü Fethi'l-Kadîr, 2: 274.

37 Sehnûn, el-Müdevvene, 1: 297; Karâfî, ez-Zahîre, 3: 141; Girnâtî, el-Kevâninü T-fikhiyye, 214.

38 Şâfiî, el-Ümm, 3: 200; Mâverdî, el-Hâvi'l-kebîr, 8: 535; Nevevî, el-Mecmû', 6: 222. 
Hanbelîler'e göre aralarında zekât vermenin caiz olmayacağı kimseler sadece anne-baba, çocuk, torun, dede ve ninelerdir. Bunların birbirine mirasçı olup olmamasının arasında bir fark yoktur. Çünkü bunlar bir soyun direğidir; aralarında genelde mülkten yararlanma ilişki ve nafaka sorumluluğu bulunan kimselerdir; birinin öbürüne zekât vermesi üzerine vacip olan nafakadan kaçmak, malı bir açıdan kendine vermek sayılır. Kardeş ve amca gibi yakın akrabalara gelince bunlardan herhangi bir sebepten dolayı zekât sahibi akrabasına mirasçı olamayan kimseye zekât verilmesinde bir sakınca yoktur. Meselâ bir mal sahibi, oğlu ve amcası gibi üç kişinin olduğunu varsayalım. Bu durumda mal sahibinin oğlu mal sahibinin amcasını mirastan mahrum bıraktığı için amca, mal sahibine mirasçı olamaz. Dolayısıyla amcanın mal sahibinden zekât alması caizdir. Birbirine mirasçı olabilecek yakın akrabalarına zekât verilmesinin caiz olup olmaması hususunda Hanbelîler arasında ihtilaf mevcut olup kimine göre caiz, kimine göre caiz değildir. Caiz olduğunu savunanların görüşü Hanbelî mezhebinde daha güçlü görüş olarak kabul edilmiştir. Ayrıca zevi'l-erhâm olan yakın akrabalar mirasçı olsa bile zekât alabilirler. ${ }^{39}$

Yukarıda zikredilen akrabalardan aralarında zekât vermenin veya almanın caiz olmayacağı kimselerin dört mezhep fakihlerine göre anne-baba ve çocukların, bazı Mâlikî dişındaki fakihlere göre anne-baba ve çocuklara ilaveten dede-nine ve torunların olduğu anlaşılmaktadır. Bazı Hanbelîler hariç diğer fakihlere göre yakın akrabaların birbirinden zekât almaları caizdir. Usul ve fürûların birbirlerinden zekât almalarının caiz olmayacağına dair ne Kur'an'dan ne de hadisten delil vardır. Bu hususla ilgili ortaya konulanlar ise görüldüğü gibi sadece nafaka ile zekâtı ilişkilendirerek ileri sürülen aklî delilden ibarettir.

\subsection{Zekât Verilmesinin Caiz Olduğunu Savunanlar}

Usul ve fürû arasında zekât verme veya almanın caiz olmayacağını savunan fakihlere karşın kimi fakihler, bazı durumlarda onların da birinin öbüründen zekât almalarının caiz olacağını söylemişlerdir. Şâfiîler ve Hanbelîler'e göre aralarında nafaka sorumluluğu bulunan kişiler birbirinden fakir, miskin sınıfların dışındaki diğer sınıfların biriyle zekât alabilirler. Örneğin; köle, mücahit, borçlu veya zekât toplama memuru olan bir kimse babasından, dedesinden, oğlundan veya torunundan zekât alabilir. Şâfiîler borç alınma nedenini dikkate almazken Hanbelîler ise kendi harcamalarına kullanmak amacıyla değil sadece küs taraftarları barıştırmak maksadıyla alınmış olmasının gerekliliğini ileri sürmüşlerdir. ${ }^{40}$

39 İbn Kudâme, el-Mugnî, 4: 98-99; Merdâvî, el-İnsâf, 3: 254-260; Ebû İshâk Burhaneddin İbrâhim b. Muhammed b. Müflih, el-Mübdi' fi Şerhi'-Mukni', thk. Muhammed Hasan Muhammed Hasan İsmail eş-Şâfiî, (Beyrut: Dârü'l-Kütübi'l-İlmiyye, 1418/1997), 2: 418-423.

40 Mâverdî, el-Hâvi't-kebîr, 8: 535-536; Nevevî, el-Mecmû', 6: 222; Abdurrahman b. Abdullah el-Ba'lî el-Hanbelî, Keşfü̈l-muhadderât ve'r-riyâzü'l-müzhirât li Şerhi Ahsari'l-muhtasarât, thk. Muhammed b. Nâsır el-'Acmî, (Beyrut: Dârü'l-Beşâiri'l-İslâmiyye, 1423/2002), 269. 
Şâfiî ve Hanbelî kaynaklarında zekât memuru hariç diğer sınıfların zekâtı, bir kurum aracığıyla almasının gerekli olup olmadığına dair herhangi bir kayıt bulunmamaktadır. Ancak o kimselere zekât verilmesinin caiz olduğunu ifade eden ibarenin yapısına bakılırsa zekâtın kurum aracığıyla almasının gerekli olmadığı anlaşılmaktadır. Söz konusu ibare: "Zekât, zekât veren kişinin babasına, annesine, dedesine, ninesine, çocuklarına, torunlarına verilmez ancak bunların zekât memuru, mücahit veya borçlu olmaları.... İstisnadır." ${ }^{41}$ şeklindedir. Kanaatimizce bir kişinin kendi usul veya fürûlarından zekât alabilecekleri durumların istisna olarak zikredilmesi, bunlara zekâtın kurum vasıtasıyla değil direk elden verilmesinin de caiz olacağını göstermektedir. Zira daha önce ifade ettiğimiz gibi bir kimsenin kurum aracılı̆̆ıla sadece zekât memuru, mücahit sıfatıyla değil fakir ve miskin sıfatıyla babası veya çocuğu tarafindan kuruma verilen zekâtı alması tüm fakihlere göre de caizdir.

Usul ve fürû arasındaki zekât meselesi ile ilgili hususlarda en geniş yolu izleyen âlimin İbn Teymiyye (ö. 728/1328) olduğu görülmektedir. İbn Teymiyye’ye göre usul ile fürûlar sadece köle, mücahit, borçlu veya zekât toplama memuru sıfatıyla değil gerekirse fakir ve miskin sıfatıyla da birbirinden zekât alabilirler. Üzerine vacip olan nafakayı fakir ve miskin olan babasına, oğluna, torununa, dedesine ve ninesine ödemeye gücü yetmeyen kimse zekâtını, söz konusu kişilere verebilir. Zira zekât alması için fakir ve miskin olmaktan ibaret sebep mevcut olup zekâtın verilmesine mani olacak herhangi bir durum yoktur. ${ }^{42}$

Kar1-koca; Fakihler tarafından benimsenen görüşlerden biri kocanın eşine zekâtını vermesinin caiz olmamasıdır. Hatta bu hususta icmâ olduğu ileri sürülmüştür. Çünkü koca eşine bakmakla yükümlüdür. Ancak kadının kocasına zekâtını vermesinin caiz olup olmamasıyla ilgili ihtilaf mevcuttur. Ebû Hanife, İmam Mâlik ve kimi Hanbelîlerce kadının kocasına zekâtını vermesi caiz değildir. Çünkü bunların arasında menfaat ortaklığı vardır ve kadının kocasına zekâtını vermesi malı, sanki kendisine vermiş sayılır. Ebû Yusuf, İmam Muhammed, Şâfiîler ve bazı Hanbelîler'e göre kadının kocasına zekâtını vermesi caizdir. Bu görüş sahipleri, yoksul kocasına ve yanındaki yetim çocuklara sadakada bulunmanın doğru olup olmadığını soran Abdullah b. Mes'ud'un (ö. 32/652) hanımı Zeynep'e Peygamber (s.a.v.)'in, söylediği: "İkişer ecir vardır; Akrabalık ecri ve sadaka ecri." ${ }^{43}$ hadisini delil olarak getirmişler-

41 Ba'lî, Keşfül-muhadderât, 269.

42 Şeyhü'l-İslâm Takiyyüddin Ahmet b. Teymiyye el-Harrânî, Mecmû'etül-fetâvâ, i'tina ve thrc. Amir Cezzar, Enver Baz, 3. bs. (Mansure: Dârü'1-Vefa, 1426/2005), 25: 54.

43 Ebü'l-Hüseyin Müslim b. Haccac el-Kuşeyri en-Nîsâbûrî, Sahîhü Müslim, i'tina, Ebû Kuteybe Nazer Muhammed el-Fariyabi, (Riyad: Dârü Tayyibe li'n-Neşr ve't-Tevz,1427/ 2006), "Zekât", 45. 
dir. Karşı görüştekiler bu hadisteki sadakadan maksadın zekât değil, nafile sadaka olduğunu ileri sürmüşlerdir. ${ }^{44}$

Bunlar, fakihlerin bu hususta ileri sürdükleridir. Fakihlerin bu görüşlerine kendi kanaatimizi ekleyerek aralarında nafaka sorumluluğu bulunan kişilerin şu durumlarda birbirlerinden zekât alabileceklerini söylememiz mümkündür:

\subsubsection{Borçlular}

Mal sahibi zekâtını borçlu olan ve ödemeye gücü yetmeyen babasına, annesine, dedesine, ninesine, çocuğuna, torununa veya eşine verebilir. Borç muamelesinde borcu ödeme sorumluluğu sadece borcu alan kimseye aittir. Çünkü borçta zimmet esastır. Borç kimin zimmetindeyse onu ödemek babası veya çocuğu gibi başka birinin değil sadece onun üzerine düşer. Borçlunun hangi amaç için borç aldığı dikkate alınmalıdır. Burada "Borçlunun borcu küs taraftarları barıştırmak için alması gerekir." diyen Hanbelîlerin hassasiyetine büyük ölçüde katılmakla birlikte borçların sadece küsleri barıştırmak gibi toplumun yararı için kullanılması amacıyla alınmış olmasının şart olmadığını, dolayısıyla gerekli ihtiyaçların karşılanması maksadıyla alınan borçlar için de zekât verilebileceğini söyleyebiliriz. Sebep ne olursa olsun borçlunun "Borcum akrabalarımın zekâtlarıyla bir şekilde ödenecek." düşüncesiyle harcamalarda aşırılığa gitmemesi ve zekât ile borcunu kapattırmayı âdet haline dönüştürmemesi gerekir. Aksi takdirde zekât kendi amacı dışında kullanılmış olacaktır.

\subsubsection{Bașkalarına Bakmakla Yükümlü Olanlar}

Kalabalık bir aileye sahip ve kazandıkları ailenin ihtiyaçlarını gidermeye yetmeyen bir kimsenin, babasından veya varlıklı çocuğundan zekât almasında bir sakınca yoktur. Verilen zekât genelde ailenin ihtiyaçlarına kullanılacağı ve aile fertlerinin nafakasından asıl sorumlu olan aile reisi baba olduğu için bir babaya, babası veya varlıklı çocuğu tarafından verilen zekât nafakasından sorumlu olan kimseye verilmiş sayılmayacaktır. Gerçi Hanefîler, kardeşin nafakasının kardeşine ait olacağını ileri sürmüş olsa da onlara göre de kardeşlerin birbirinden zekât almaları caizdir. Nafakasını vermeye gücü yetmeyen bir babanın çocuklarının nafakasının, çocukların dedesine ait olacağı daha önce zikredildiği gibi ihtilaflıdır. Dolasıyla bir dedenin, çocuklarına bakmakta zorlanan çocuğuna zekâtını vermesi kimi fakihlere göre caizdir. Kanaatimizce muteber bir mezhep tarafından desteklenen bir görüşe uymanın herhangi bir sakıncası yoktur. Bir koca, bakmakla yükümlü olduğu annesi, babası veya başka kocadan çocukları olan eşine zekâtını verebilir. Çünkü bir kocanın sorumlu olduğu nafaka sadece eşinin nafakasıdır.

44 Serahsî, el-Mebsût, 3: 11-12; Karâfî, ez-Zahîre, 3: 14l; Mâverdî, el-Hâvi'l-kebîr, 8: 536-537; Müflih, el-Mübdi', 2: 423. 


\subsubsection{Kalpleri İslâm’a Isındırılacak Olanlar}

Daha önce zikredildiği gibi kimi fakihe göre bu sınıftaki kişilerin zekâttaki payı iptal edilmiş, kimine göre kıyamete kadar devam edecektir. Günümüzdeki gibi müslümanların durumunun, içinde bulundukları sıkıntılardan dolayı desteklenmeye veya daha kötüye gitmesinin engellenmeye ihtiyacı olduğu bir dönemde bir kimse zekâtını vererek babasının, çocuğunun veya eşinin desteğini alması veya onların şerrinden korunması mümkünse, o kimsenin zekâtını onlara vermesinde bir mani yoktur.

\subsubsection{Fakir ve miskinler}

Aralarında nafaka sorumluluğu bulunan kişilerin fakir ve miskin sıfatıyla birbirlerinden zekât alabilecekleri sadece İbn Teymiyye'ye göre caizdir. İbn Teymiyye, bu kişilerin birbirlerinden zekât alabilmeleri için kendilerinde fakirlik sıfatının bulunmasının yeterli olacağını ileri sürmüştür. Düşüncemizce onların zekât müessesini kendi aralarında malları elden ele dolaştıracak bir araç haline dönüştürmemeleri için kendilerinde fakirlik sıfatının bulunmasının yanı sıra zekâtı veren ve alanların niyetlerinin halis ve samimi olmaları da çok önemlidir.

Aralarında nafaka sorumluluğu bulunan kişilerin söz konusu durumlarda birbirlerinden zekât alabilecekleri kanaatine varmamızı sağlayan faktör, onların bu gibi durumlarda zekât alabileceklerini yasaklayan herhangi bir delilin Kur'an'da veya hadiste bulunmamasıdır. Ayrıca ayette zekât verilecek kişiler mutlak şekilde zikredilmiştir. Dolayısıyla nafaka sorumlusu ile alacaklılar da ayete göre zekât alabilecek ve verebilecek kişilerdir. Ancak fakihler, bunların birinin öbüründen zekât alamayacağı yönündeki görüşlerini daha önce zikredildiği gibi açık delilden ziyade zekât ile nafaka müessesinin ilişkilendirildiği içtihat üzerine bina etmiş ve nafaka alacak olan taraf nafaka sorumlusundan zekât alamaz hükmüne varmışlardır. Fakihler, böyle bir içtihat yaparken kimi yerlerde çelişkiye düşmüşlerdir. Meselâ kimi fakihler, kardeşleri birbirlerinin nafakalarından sorumlu tutarken kendi aralarında zekât verip almalarını caiz görmüş, kimi fakihler de anneyi çocuğunun nafakasından sorumlu tutmazken annenin çocuğundan veya çocuğun annesinden zekât almalarını doğru bulmamışlardır. Böylece "Nafaka alan zekât alamaz." hükmü delilin değil bir içtihadın ürünü olduğu anlaşılmaktadır. Kimi içtihat değişkendir. Bunları ileri sürerek varmak istediğimiz sonuç ise "nafaka alan zekât alamaz" içtihadının gerekli görüldüğünde değişmesi ve şartların oluşması halinde nafaka sorumlusu ile alacaklıların da zekât alıp verebilmeleridir. Burada belirtmemiz gereken şey şu ki akrabasına ya da eşine zekât veren kimsenin verdiği zekâtı, vermesi gerekli olan nafakanın yerine saymaması ve nafakayı eksiltmeden vermeye devam etmesidir. 


\section{SONUÇ}

İslâm'ın beş temel esaslarından biri olan zekâtın farziyeti Kur'an, sünnet ve icmâ ile sabit olmuştur. İslami literatürlerde zekâtın farz kılındığı zaman ve yer ile ilgili genel eğilimin, zekâtın hicretin ikinci yılında Medine'de farz olduğu yönünde olmasına karşın araştırmalar bize zekâtın Mekke ve Medine dönemi olmak üzere birkaç aşamada tedrici bir şekilde farz kılınmış olduğunu ortaya koymuştur. Zekâtın ayet tarafından açıklanan hükümlerinden biri zekâtın verileceği sınıflar olup bunlar fakirler, miskinler, zekât toplayan memurlar, kalpleri İslâm'a 1sındırılacak olanlar, köleler, borçlular, Allah yolunda olanlar ve yolda kalmış yolculardır. Fakihler, bu sınıfların zekât alabileceği hususunda büyük ölçüde ittifak etmiş olsalar da onların mezkûr sınıflardan kimlerin kastedildiğiyle ilgili ihtilafa düştükleri görülmüştür.

Fakihler, kendi ihtiyaçlarını karşılamakta zorlanan kimsenin nafakasından, akrabaları içinden maddî imkânı müsait olan birinin sorumlu olacağı meselesinde ittifak ederken nafaka sorumlusu ile alacakların tespitinde ihtilafa düşmüşlerdir. Hanefîler'e göre nafaka sorumlusu ile alacaklar anne-baba, dede, nine, çocuklar, torunlar gibi usul ve fürûlar, kardeş ve amca gibi yakın akrabalardır. Mâlikîler, nafaka sorumlusu ile alacakların sadece anne-baba ve çocuklar olduğunu benimsemişlerdir. Şâfiîler onları usul ve fürû olarak belirlemişlerdir. Hanbelîlerce onlar usul, fürû ve miras yollarından biriyle birbirine mirasçı olanlardır. Tüm fakihlere göre kadının nafakası kocasına aittir. Nafaka sorumlusu ile alacakların tespitinde kimi yerlerde ayete başvurulurken kimi yerlerde de içtihada başvurulduğu görülmüştür. Bu, nafaka sorumlusu ile alacakların belirtilmesinde fakihler arasında ihtilaf yaşanmasına sebep olmuştur.

Fakihler, aralarında nafaka sorumluluğu bulunan kişilerin kendi aralarında zekât verip almalarının caiz olup olmaması konusu üzerinde durmuşlardır. Onların esas aldıkları ölçüt, zekât ile nafaka arasını ilişkilendirmek olmuş, aralarında nafaka sorumluluğu bulunan kişilerden birinin öbüründen zekât almalarının doğru olmadığ1 sonucuna varmışlardır. Fakihlerin genel kanaati bu yöndedir. Ancak kimi fakihin bazı yerlerde bu genel kanaatin dışına çıktığı ve kimi durumlarda da onların kendi aralarında zekât alıp verebileceklerini ileri sürdükleri görülmüştür. Meselâ Hanefîler, kardeş ve amca gibi yakın akrabaları, nafaka sorumlusu ile alacaklarından saymasına rağmen birbirlerinden zekât alabileceklerini, Şâfiîler ile Hanbelîler ise aralarında nafaka sorumluluğu bulunan kişilerden köle, mücahit veya borçlu olan birinin babasından, dedesinden, oğlundan veya torunundan zekât alabileceklerini söylemişlerdir. Son olarak nafaka alacaklısının nafaka sorumlusundan zekât almasının caiz olmadığ 1 görüşünün içtihadî bir mesele olduğu; zekât verilecek kişilerin ayette mutlak şekilde zikredildiği ve ayetin anlamı içine usul, fürû ve karı-kocaların da dâhil olacağı 
düşünüldüğünde ihtiyaçların ortaya çıkması ve şartların oluşması halinde usul, fürû ve kar1-kocanın birbirinden zekât almalarının doğru olacağı yönünde bir kanaatin oluştuğu sonucuna varılmıştır.

\section{KAYNAKÇA}

Âlûsî, Şihâbüddin Seyyid Mahmud el-Bağdadî. Rûhu'-Meânî fî tefsîri'Kur'âni'l-azîm. Beyrut: Dârü İhyai't-Türâsi'l-Arabî, ts.

Ba'lî, Abdurrahman b. Abdullah el-Hanbelî. Keşfü'l-muhadderât ve'rriyâzül-müzhirât li Şerhi Ahsaril-muhtasarât. (Thk: Muhammed b. Nâsır el'Acmî). Beyrut: Dârü'l-Beşâiri'l-İslâmiyye, 1423/2002.

Buhûtî, Şeyh Mansur b. Yunus b. İdris el-Hanbelî. Keşşâfü '-kınâ'ani'l-iknâ'. (Thk: Lecnetün Mütehassisetün fi Vizâretü'l-Adli). b.y. 1421/2000.

Burnehâbûrî, Şeyh Nizam. el-Fetâval-Hindiyye. (Zbt ve tsh: Abdullatif Hasan Abdurrahman). Beyrut: Dârü'l-Kütübi'l-İlmiyye, 1421/2000.

Bustânî, Butrus. Muhîtu'l-Muhît. Beyrut: Mektebetü Lübnan, 1407/1987.

Cessâs, Ebû Bekr Ahmet b. Ali er-Râzî. Ahkâmü̈l-Kur'ân. (Thk: Muhammed es-Sadık Kamhavi). Beyrut: Dârü İhyai't-Türâsi'l-Arabî, 1412/1992.

Cürcânî, Ali b. Muhammed es-Seyyid eş-Şerif. Mu'cemü't-Ta'rîfât. (Thk: Muhammed Sıddık el-Minşâvî). Kahira: Dârü'l-Fadile, ts.

Dusûkî, Şemsüddin eş-Şeyh Muhammed Urfe. Hâşiyetü'd-Dusûkî ale'şŞerhi'l-kebîr. Kahire: Dârü Ihyâ'i 'l-Kütübi '1-'Arabiyya, ts.

Ebû Hayyan, Muhammed b. Yusuf, el-Endülüsî. el-Bahru'-muhît. (Thk: Adil Ahmet AbdülMevcud ve Ali Muhammed Muavvez). Beyrut: Dârü'1Kütübi'l-İlmiyye, 1413/1993.

Erbay, Celal. "Nafaka”. Türkiye Diyanet Vakfı İslam Ansiklopedisi. 32: 282. Ankara: DTV Yayınları, 1427/2006.

Gırnâtî, Ebû'1-Kasım Muhammed b. Ahmet b. Cüzey el-Kelbi el-Mâlikî. el-Kevâninül-fikhiyye. (Thk: Muhammed b. Seydi Muhammed Mevlay). b.y. ts.

Heyet. "İslam". el-Mevsûâtu'l-fikhiyye. 2. bs. 4: 270. Kuveyt: Vizâretü'1Evkâf ve'ş-Şuûni'l-İslâmiyye, 1406/1986.

İbn Âbidîn, Muhammed Emin b. Ömer b. Abdülaziz ed- Dımaşki. Hâşiyetu İbn Âbidîn, reddü'l-muhtâr alâ dürri'l-muhtâr. (Thk: Adil Ahmet Abdülmevcud, Ali Muhammed Muavviz). Riyad: Dârü Âlemi'l-Kütüb, 1424/2003. 
İbnü'1-Hümâm, Kemâleddin Muhammed b. Abdülvahid b. Abdülhamid. Şerhü Fethi'-Kadîr. (Thk ve thrc: Abdurrezzak Gālip el-Mehdi). Beyrut: Dârü'lKütübi'l-İlmiyye, 1424/2003.

İbn Kesir, Ebû'l-Fida İmadüddin İsmail b. Ömer. Tefsirü̈l-Kur'anil-âzîm. (Thk: Sami b. Muhammed es-Selâme). 2. bs. Riyad: Dârü Tayyib li'n-Neşr ve't-Tevz, 1420/1999.

İbn Kudâme, Ebû Muhammed Muvaffakuddin Abdullah b. Ahmet. elMugnî. (Thk: Abdullah b. Abdülmuhsin Türkî ve Abdülfettah Muhammed el-Hulv). 3. bs. Riyad: Dârü Âlemi'l-Kütüb, 1417/1997.

İbn Kudâme, Ebû Muhammed Muvaffakuddin Abdullah b. Ahmet. elKāfí, (Thk: Abdullah b. Abdülmuhsin Türkî). Cize: Hicr li't-Tıbâa ve'n-Neşr, 1417/1997.

İbn Mâce, Ebû Abdullah Muhammed b. Yezid el-Kazvinî. Sünenü İbn Mâce. (Thrc ve tlk: Muhammed Nasırüddin Albeni). Riyad: Mektebetü'1Me'ârif, ts.

İbn Menzûr, Ebû'l-Fazl Cemaluldin Muhammed b. Mükerrem el-İfrikî el-Mısrî. Lisânü̈l-Arab. Beyrut: Dârü Sadır, ts.

İbn Müflih, Ebû İshâk Burhaneddin İbrâhim b. Muhammed. el-Mübdi' fî Şerhi'-mukni'. (Thk: Muhammed Hasan Muhammed Hasan İsmail eş-Şâfiî). Beyrut: Dârü'l-Kütübi'l-İlmiyye, 1418/1997.

İbn Teymiyye, Şeyhü'-İslâm Takiyyüddin Ahmet el-Harrânî. Mecmû'etü'tfetâvâ. (I'tina ve thrc: Amir Cezzar, Enver Baz). 3. bs. Mansure: Dârü'l-Vefa, 1426/2005.

Karâfî, Şehabeddin Ahmet b. İdris. ez-Zahîre. (Thk: Muhammed Hacci). Beyrut: Dârü'l-Garbi'l-̇̇slâmî, 1414/1994.

Kahtânî, Said b. Ali b. Vahpe. ez-Zekât fi't-İslam. 3. bs. Kasb: Merkezü'dDe've ve'l-İrşâd, 1431/2010.

Karaman, Hayreddin. İslâm hukuku tarihi. İstanbul: Nesil Yayınları, 1409/1989.

Karevî, Muhammed el-Arabî. el-Hulâsatul-fikhiyye alâ mezhebi's-sâdetilMâlikiyye. Beyrut: Dârü'l-Kütübi'l-İlmiyye, ts.

Kāsânî, Alâeddin Ebû Bekr b. Mes'ud el-Hanefî. Bedaiü's-sanâi' fì tertibi'şşerâi'. (Thk: Ali Muhammed Muavvez ve Adil Ahmet AbdülMevcud). 2. bs. Beyrut: Dârü'1-Kütübi'l-İlmiyye, 1424/2003. 
Mâverdî, Ebü'l-Hasan Ali b. Muhammed b. Habib. el-Hâvi'l-kebîr fi fikh mezhebi'ş-Şafî̀. (Thk: Ali Muhammed Muavviz ve Adil Ahmet abdülmevcud). Beyrut: Dârü'l-Kütübi'l-İlmiyye, 1414/1994.

Mecme'ü'1-Luğâti'l-Arabiyye. el-Mu'cemül-vesît. 2. bs. İstanbul: elMektebetü'l-Islamiye, ts.

Merdâvî, Alâeddin Ebû'l-Hasan Ali b. Süleyman. el-İnsâffì Me'rifeti'r-râcih mine'-hilâfalâ mezhebil-imami'l-mübeccel Ahmet b. Hanbel. (Tsh ve thk: Muhammed Hamid Fiki). 2. bs. Beyrut: Dârü İhyai't-Türasi'l-Arabî, 1374/1986.

Müslim, Ebü'1-Hüseyin b. Haccac el-Kuşeyri en-Nîsâbûrî. Sahîhü Müslim. (I'tina: Ebû Kuteybe Nazer Muhammed el-Fariyabi). Riyad: Dârü Tayyibe li'n-Neşr ve't-Tevz, 1427/2006.

Nemri, Ebû Ömer Yusuf b. Abdullah b. Muhammed b. Abdulber elKurtubî. el-Kāfí fi fikhı ehlili-Medinetil-Mâlikî. 2. bs. Beyrut: Dârü'l-Kütübi'lİlmiyye, 1413/1992.

Nesâî, Ebû Abdirrahman, Ahmet b. Şuayb. es-Sünenül-kübrâ. (Thk ve thr: Hasan Abdul Mun'im Şelbî). Beyrut: Müessesetü'r-Risâle, 1421/2001.

Nevevî, Ebû Zekeriyyâ Muhyiddin Yahyâ b. Şeref b. Nuri. el-Mecmû Şerhü'-mühezzeb li'ş-Şîrâzî. (Thk: Muhammed Necib Mutî). Cidde: Mektebetü'l-İrşad, ts.

Râzî, Muhammed Fahreddin b. Allame Ziya'u'd-Din Ömer el-Müştehir bi Hatîbi'r-Rey. et-Tefsîrül-kebîr. Beyrut: Dârü'l-Fikr, 1401/1981.

Reşid Rızâ, Muhammed. Tefsirü̈'-menâr. 2. bs. Kahira: Dârü'1-Menâr, 1366/1947.

Sâvî, Ahmet b. Muhammed el-Mâlikî. Bulgatü's-Sâlik li-Akrebil-Mesâlik ala Şerhi's-Sagâr. (Tsh: Muhammed Abdüsselam Şahin). Beyrut: Dârü'1-Kütübi'1İlmiyye, 1415/1995.

Sehnûn, Abdüsselam b. Seîd Tenûhî. el-Müdevvenetül-kübra. Kahire: Matbaatü's-Saâde, 1323/1905.

Serahsî, Şemsüleimme Ebû Bekr Muhammed b. Ebi Sehl. el-Mebsût. Beyrut: Dârü'l-Me'rife, 1409/1989.

Şâfiî, Muhammed b. İdris. el-Ümm. (Thk: Rıfat Fevzi Abdülmuttalib). Mensura: Dârü'l-Vefa, 1422/2001.

Useymîn, Muhammed b. Salih. Fetâva fi ez-zekât ve's-siyâm. (Nşr: Fahd b. Nasir b. İbrahim es-Süleyman). Riyad: Dârü's-Süreyya, 1429/2008.

Zebidi, es-Seyyid Murteza el-Hüseyn. Tâcu'-Ârûs min cevâhiril-Kāmûs. 
(Thk: Abdu's-Subûr Şâhîn). Kuveyt: el-Meclisu'l-Vatanî li's-Sikâfe ve'l-Funûn ve'l-Edeb, 1422/2001.

Zebidi, es-Seyyid Murteza el-Hüseyn. Tâcul-Ârûs min cevâhiril-Kāmûs. (Thk: Hüseyin Nessâr). Kuveyt: Vizâretü'1-I’lâm, 1394/1974.

Zuhaylî, Vehbe. el-Fıkhu'-İslâmî ve edilletuh. 3. bs. Beyrut: Dârü'l-Fikr, 1409/1989.

Zuhaylî, Vehbe. et-Tefsirü 'l-münir: fi l-akideti ve'ş-şeria ti ve'l-menhec. 10. bs. Dımaşk: Dârü'l-Fikr, 1430/2009. 